\title{
Methods of increasing efficiency and acceleration of selection process in breeding of new breeds, types, and lines in pig husbandry
}

\author{
A.A. Novikov ${ }^{1, *}$, G. S. Pokhodnya ${ }^{2}, P$. I. Breslavets ${ }^{2}$, V.P. Zhabinskaya ${ }^{3}$, and $Y u . P$. \\ Breslavets $^{2}$ \\ ${ }^{1}$ All-Russian research institute of livestock breeding, Lenina Str., 13, Lesnye Polyany, Pushkin City \\ Okrug, 141212 Moscow region, Russian Federation \\ ${ }^{2}$ Belgorod State Agrarian University named after V.Ya. Gorin, Vavilova Str., 1, Maysky, 308503 \\ Belgorod region, Russian Federation \\ ${ }^{3}$ Department of Internal and Personnel Policy of Belgorod Region, Sobornaya Square, 4, 308005 \\ Belgorod, Russian Federation
}

\begin{abstract}
Within the framework of the national educational center "Innovative solutions in the agro-industrial complex", created by the order of the Governor of the Belgorod region in July 2019, scientists of the ALLRussian research Institute of breeding (Vniiplem), the Belgorod state agrarian University named after V.Y. Gorin (Belgorod state agrarian University) and specialists of the APC "Gorin collective Farm" (Belgorod region, Bessonovka village) developed an innovative project to create in the Belgorod region intra-breed type of pigs of a large white Breed. This project is planned to be implemented within the framework of the scientific and production platform "Selection and genetic research, cell technologies and genetic engineering: animal husbandry" using modern genetic methods and approaches. Due to the introduction, development and practical use of high-tech methods of breeding work, it is planned to create a type of large white breed pigs that can compete with the best foreign breeding achievements by 2025 , not only in terms of productivity, in particular, obtaining from one sow per year up to four tons of pork in live weight, but also, most importantly, to consistently show the effect of heterosis when used in hybridization programs.
\end{abstract}

\section{Introduction}

Improvement of breeding and productive qualities of animals at home is carried out by various methods, including genetic - cross-breeding and breeding, and paratypical feeding, keeping and production technology $[1,2]$. Genetic improvement of pigs means improvement of economic traits, which is achieved both by breeding methods - purebred breeding, cross-breeding and hybridization, and selection methods - animal selection and pairing [3, 4, 5]. Traditionally, the selection and pairing of animals are the main components of the breeding process; its focus is determined by the goals and objectives of

\footnotetext{
${ }^{*}$ Corresponding author: novikov-41@mail.ru
} 
genetic improvement. As a rule, the final result of the breeding process is the formation of the genetic potential of animals' productive qualities in accordance with the requirements of the modern market $[6,7]$. Due to changing demand, market conditions may also change, which determines the need to develop new breeds, types and lines. Thus, the main purpose of genetic improvement is the formation of animals' genetic potential on certain economic traits by changing heredity or individual genome $[3,8]$.

Improvement of animals' productive qualities by paratypical methods is aimed at increasing the level of genetic potential realization that do not change the heredity (genome) of animals. Despite the fundamental difference between genetic and paratypical methods, their influence on the course of the breeding process is nevertheless interdependent. The level of animals' productivity, including pigs, is determined by their genetic potential and the level of its realization [9]. With insufficient genetic potential realization level, methods of genetic improvement, particularly selection and pairing, are useless since in this case the breeding process will be aimed at forming a herd consisting of highly mediocre animals. At the same time, the efficiency of the selection process will be zero and the timing of the given goal achievement will be lengthened [3, 4].

Thus, an indispensable condition for the "right" genetic improvement is the goaladequate maximum level of animals' genetic potential realization $[10,11,12]$. However, in fulfilling this condition, the effectiveness and timing of genetic improvement is affected by many factors - both at the population and at the individual level. At the same time, at the population level such breeding and genetic parameters as the trait inheritance factor, trait variability, its correlation with other traits, as well as a repeatability rate are important. Among genetic data, indicators of homo- and heterozygosity, genetic diversity, frequency of population occurrence $[13,14]$ are of great importance.

At the individual level, the animal breeding value is the most important; it is expressed through an index of breeding value on one or more economical traits. The main factor of the animal's breeding value is the genome, its variability potential during reproduction and resistance to environmental influences $[15,16]$.

In recent years, due to the dynamic development of genetic and biotechnological methods, modern approaches to breeding have undergone significant changes [17]. However, at present, the basis of breeding efficiency is the traditional approach, since the main breeding feature is the animal productivity. All other techniques are optional. Their main task is to increase the breeding efficiency and accelerate the selection process. Information technologies that allow to automate and update the selection results in the system online $[1,4,5]$ are of great importance.

The aim of the research was to analyze modern breeding technologies and requirements for creating a selection program for the breeding of intra-breed type of large white pigs in Belgorod region. At the first stage of creating an intra-breed type of large white pigs, it was necessary to study the reproduction function and productivity of this breed's animals belonging to the "Kolkhoz named after Gorin»" agricultural production co-operative (APCO).

\section{Conditions, materials, and methods}

In the field of pig breeding and taking into account modern scientific Russian and foreign achievements, a number of high-tech breeding methods have been developed in FSBSI "VNIIplem". Thus, in 2017-2018 together with software specialists of "Selikom" LLC, FSBSI "VNIIplem" developed an evaluation methodology for breeding value of pigs based on the BLUP method (Best Linear Unbiased Prediction).

Despite the theoretical development of this method by Cornell University professor C. R. Henderson back in the 70 -ies, as well as its universal recognition by the scientific 
community, it has not been applied in practical breeding in our country. The advantages of the method are the calculation of the animals' breeding value considering the many causal factors affecting its productivity, as well as statistical non-distortion in calculations.

For a more accurate assessment of animals' breeding value, its own equation-index is derived for each individual, considering many factors, including data for all relatives, influence of the external environment, transmission level of productivity to descendants, correlation between traits, economic weight of traits. Based on the breeding values of each animal, the average value of the total breeding value is calculated by population.

Animals with a value above this indicator are included in the further breeding process, and animals with values below average are generally excluded.

\section{Results and discussion}

Despite the clear advantages of the BLUP method over score and class evaluations, its accuracy can be greatly improved through the use of genetic technologies. A detailed study of the animal genome and identification of genes that determine the values of selectable traits allows to predict the breeding value of animals at a very early age. On the basis of genomic prognosis, it is possible to select and grow young animals without waiting for its evaluation in adult age. This technique allows to significantly accelerate the selection process, while increasing the accuracy of the evaluation. It is also possible to supplement the BLUP breeding value index with the value of genomic prognosis and further increase the accuracy of BLUP estimation based on the results of the own productivity of the proband under estimation and after obtaining its progeny.

The abovementioned advanced breeding technologies increase both breeding efficiency and significantly accelerate the breeding process. But in order for the selection process to follow the planned path, constant control of its orientation and appropriate adjustment at the population level is necessary. To this end, the FIAS computer program (Federal Information and Analytical Service) has been developed at the FSBSI "VNIIplem". The main purpose of this program: to promptly make appropriate changes to the selection based on data of individual estimates of animals' breeding value and automatic calculation of all breeding and genetic parameters, including the most important parameters as the degree of consanguinity (imbreeding, level of homozygosity, degree of genetic diversity, homogeneity, stability, inheritance dynamics of selectable traits). Tools for correcting the selection process are changes in indices, weight coefficients of traits, preferences of certain genetic markers, changes in the level of homo- and hetorozygosity etc. With this, the level of breeder's professionalism, his intuition, the mastery of eye assessment of each animal and herd as a whole are of great importance. An indispensable condition for successful breeding work is the accuracy of the primary accounting of each selection trait. At the same time, the fundamental factor here will be the integrity of persons carrying out such work, and only then software products that filter erroneous data.

The above breeding technologies and requirements are integral elements of the breeding program for obtaining intra-breed type pigs of large white breed in Belgorod region.

Work on creating a new type of pigs was carried out since January 2020 by FSBSI "VNIIplem" in collaboration with scientists and specialists of FSBEI HE Belgorod SAU and APCO "Kolkhoz named after Gorin" in Belgorod region.

At the first stage of creating a large white intra-breed type for an objective assessment of the large white boars' breeding qualities belonging to the APCO "Kolkhoz named after Gorin", studies have been conducted to study the reproducible function and productivity of these animals. 6 adult boars $(2.0 \ldots 2.5$ years) of large white breed ( 3 boars of the "Olymp V" line and 3 boars of the Topigs 1 line) were selected for the experiment based on analogues. 
Conditions of experimental boars' feeding and keeping complied with the standards of the Federal Scientific Center of Livestock - VIJ named after academician L. K. Ernst. Boars' sperm sampling, definition of quantitative and qualitative indicators was also carried out according to the methods of this scientific center.

Sows oestrum was detected using trailer boars twice a day: at 8 am and $1 \mathrm{pm}$. Artificial insemination of sows was carried out with the help of disposable catheters twice: the first time immediately after the establishment of oestrum and after 24 hours. A $100 \mathrm{ml}$. dose of sperm with a content of $2.5-3.0$ billion mobile sperm cells was used for insemination.

It was established that the large white breed boars belonging to the Olymp V and Topigs 1 lines according to the quantitative parameters of sperm do not differ significantly (Table 1). These indicators fully comply with the standards for large white breed boars.

Table 1. Quantitative indicators of large white breed boars' sperm.

\begin{tabular}{|c|c|c|c|c|c|}
\hline & & & \multicolumn{3}{|c|}{ Quantitative indicators of boars' sperm } \\
\cline { 4 - 6 } Boars line & $\begin{array}{c}\text { Number of } \\
\text { boars in a } \\
\text { group }\end{array}$ & $\begin{array}{c}\text { Number of } \\
\text { ejaculates } \\
\text { studied }\end{array}$ & Volume, ml & $\begin{array}{c}\text { Sperm cells } \\
\text { concentration } \\
\text { in 1 ml of } \\
\text { sperm, mill. }\end{array}$ & $\begin{array}{c}\text { Total } \\
\text { number of } \\
\text { sperm cells } \\
\text { in } \\
\text { ejaculates, } \\
\text { billion }\end{array}$ \\
\hline Olymp V & 3 & 30 & $305,0 \pm 11,0$ & $222,0 \pm 6,1$ & 67,7 \\
\hline Topigs 1 & 3 & 30 & $298,0 \pm 8,0$ & $228,0 \pm 7,0$ & 67,9 \\
\hline $\begin{array}{c}\text { On average } \\
\text { by lines }\end{array}$ & 6 & 60 & $301,5 \pm 9,2$ & $225,0 \pm 6,2$ & 67,8 \\
\hline
\end{tabular}

According to the qualitative sperm parameters, experimental large white breed boars of different lines also do not differ significantly. Almost all experimental boars have high quality indicators: sperm cells mobility, sperm cells resistance and ex vivo survival (Table 2).

Table 2. Qualitative indicators of large white breed boars' sperm.

\begin{tabular}{|c|c|c|c|c|c|}
\hline \multirow{2}{*}{ Boars line } & \multirow{2}{*}{$\begin{array}{c}\text { Number of } \\
\text { boars in a } \\
\text { group }\end{array}$} & \multirow{2}{*}{$\begin{array}{c}\text { Number of } \\
\text { ejaculates } \\
\text { studied }\end{array}$} & $\begin{array}{c}\text { Mobility, } \\
\text { score }\end{array}$ & Resistance & $\begin{array}{c}\text { Sperm cells } \\
\text { survival ex } \\
\text { vivo, } \mathrm{h}\end{array}$ \\
\hline Olymp V & 3 & 30 & 8,2 & $1100,0 \pm 90$ & $72,0 \pm 2,0$ \\
\hline Topigs 1 & 3 & 30 & 8,2 & $1080,0 \pm 105$ & $74,0 \pm 1,8$ \\
\hline $\begin{array}{c}\text { On average } \\
\text { by lines }\end{array}$ & 6 & 60 & 8,2 & $1090,0 \pm 98$ & $73,0 \pm 1,9$ \\
\hline
\end{tabular}

However, the main and final criterion of boars' sperm quality is the artificial insemination effectiveness of sows. Therefore, after determining quantitative and qualitative parameters of large white breed boars' sperm, artificial insemination of sows was carried out (Table 3 ).

Table 3. Effectiveness of sows' artificial insemination with large white breed boars' sperm.

\begin{tabular}{|c|c|c|c|c|c|c|}
\hline \multirow{2}{*}{ Boars line } & \multirow{2}{*}{$\begin{array}{c}\text { Number of } \\
\text { inseminated } \\
\text { sows }\end{array}$} & \multicolumn{2}{|c|}{$\begin{array}{c}\text { Of which } \\
\text { farrowed }\end{array}$} & \multicolumn{2}{|c|}{ Obtained piglets, heads } & \multirow{2}{*}{ Fetus size, kg } \\
\cline { 3 - 6 } & ber & $\%$ & Total & $\begin{array}{c}\text { For 1 } \\
\text { farrowing }\end{array}$ & \\
\hline Olymp V & 30 & 26 & 86,6 & 314 & $12,0 \pm 0,2$ & $1,29 \pm 0,01$ \\
\hline Topigs 1 & 30 & 25 & 83,3 & 305 & $12,2 \pm 0,2$ & $1,30 \pm 0,02$ \\
\hline
\end{tabular}




\begin{tabular}{|c|c|c|c|c|c|c|}
\hline $\begin{array}{c}\text { On average } \\
\text { by lines }\end{array}$ & 60 & 51 & 85,0 & 619 & $12,1 \pm 0,2$ & $1,29 \pm 0,01$ \\
\hline
\end{tabular}

The results of the study show that sows' breeding efficiency after insemination with large white breed boars' sperm is high and is on average $85.0 \%$. However, considering that APCO "Kolkhoz named after Gorin" is a breeding plant for a large white breed, the sows' prolificacy is insufficient, which must be taken into account when creating an intra-breed type of large white breed pigs. At the same time, the piglets mass index corresponds to the standards for this breed.

The offspring growth obtained from sows inseminated with large white breed boars' sperm was also studied (Table 4).

Table 4. Growth of purebred large white breed offspring.

\begin{tabular}{|c|c|c|c|c|c|c|}
\hline & \multirow{2}{*}{$\begin{array}{c}\text { Number of } \\
\text { Piglets at }\end{array}$} & \multicolumn{2}{|c|}{ Live weight, $\mathrm{kg}$} & \multirow{2}{*}{$\begin{array}{c}\text { Average } \\
\text { daily }\end{array}$} & \multicolumn{2}{|c|}{$\begin{array}{c}\text { Preservation of piglets } \\
\text { up to 6 months }\end{array}$} \\
& $\begin{array}{c}\text { pirth, } \\
\text { heads }\end{array}$ & At birth & $\begin{array}{c}\text { At 6 } \\
\text { months of } \\
\text { age }\end{array}$ & $\begin{array}{c}\text { increase } \\
\text { from birth } \\
\text { to 6 } \\
\text { months, }\end{array}$ & Heads & $\%$ \\
\hline Olymp V & 314 & $1,29 \pm 0,01$ & $106,0 \pm 0,8$ & 581 & 277 & 88,2 \\
\hline Topigs 1 & 305 & $1,30 \pm 0,02$ & $104,0 \pm 0,9$ & 570 & 272 & 89,1 \\
\hline $\begin{array}{c}\text { On } \\
\text { average by } \\
\text { lines }\end{array}$ & 619 & $1,29 \pm 0,01$ & $105,0 \pm 0,8$ & 576 & 549 & 88,6 \\
\hline
\end{tabular}

Currently, the growth of offspring obtained from sows inseminated with large white breed boars' sperm does not correspond to the parameters provided for the creation of an intra-breed type, but the experimental offspring preservation indicator is quite high and on average is $88.6 \%$.

In growing herd replacements of pigs and breeding animals, not only their growth, but also their development matter greatly. With this in mind, we have evaluated the obtained and grown up to 6 months offspring by live weight and torso length. Estimation of experimental boar pigs by live weight and torso length at 6 months of age are presented in Tables 5 and 6 .

Table 5. Evaluation of purebred boar pigs obtained from experimental boars by live weight.

\begin{tabular}{|l|l|c|c|c|c|}
\hline Boars line & $\begin{array}{l}\text { Number of } \\
\text { boar pigs } \\
\text { grown up to 6 } \\
\text { months, heads }\end{array}$ & \multicolumn{4}{|c|}{ Boar pigs' class by live weight } \\
\cline { 3 - 6 } & 132 & 52 & 1 & 2 & out of class \\
\hline Olymp V & 124 & 48 & 44 & 22 & 10 \\
\hline Topigs 1 & 256 & 100 & 94 & 47 & 15 \\
\hline $\begin{array}{l}\text { On average } \\
\text { by lines }\end{array}$ & & & & & \\
\hline
\end{tabular}

Data in Table 5 show that out of 256 boar pigs grown up to 6 months of age, $39 \%$ belonged to elite class, first class $-36.7 \%$, second class $-18.3 \%$ and only $5.8 \%$ were out of class.

Table 6. Evaluation of purebred boar pigs obtained from experimental boars along by torso length.

\begin{tabular}{|l|l|c|c|c|c|}
\hline Boars line & \begin{tabular}{l} 
Number of \\
boar pigs \\
grown up to 6 \\
\cline { 3 - 6 }
\end{tabular} & \multicolumn{4}{|c|}{ Boar pigs' class by torso length } \\
months, heads
\end{tabular}




\begin{tabular}{|l|l|l|l|l|l|}
\hline Olymp V & 132 & 52 & 44 & 25 & 11 \\
\hline Topigs 1 & 124 & 45 & 49 & 16 & 14 \\
\hline $\begin{array}{l}\text { On average } \\
\text { by lines }\end{array}$ & 256 & 97 & 93 & 41 & 25 \\
\hline
\end{tabular}

Table 6 shows that out of the 256 grown boar pigs up to 6 months of age by torso length, $37.8 \%$ corresponded to elite class, first class $-36.3 \%$, second class $-16.0 \%$, out of class $-9.7 \%$.

Estimation of experimental gilts by live weight and torso length at 6 months of age are presented in Tables 7 and 8.

Table 7. Evaluation of purebred gilts obtained from experimental boars by live weight.

\begin{tabular}{|c|c|c|c|c|c|}
\hline \multirow[t]{2}{*}{ Boars line } & \multirow{2}{*}{$\begin{array}{l}\text { The number } \\
\text { of grown } \\
\text { boar pigs up } \\
\text { to } 6 \text { months } \\
\text { of age, heads }\end{array}$} & \multicolumn{4}{|c|}{ Gilts' class by live weight } \\
\hline & & elite & 1 & 2 & $\begin{array}{l}\text { out } \\
\text { class }\end{array}$ \\
\hline Olymp V & 145 & 54 & 52 & 30 & 9 \\
\hline Topigs 1 & 148 & 51 & 50 & 32 & 15 \\
\hline $\begin{array}{l}\text { On average } \\
\text { by lines }\end{array}$ & 293 & 105 & 102 & 62 & 24 \\
\hline
\end{tabular}

Data in Table 7 show that gilts obtained large white breed boars and grown up to 6 months of age (line Olymp V and Topigs 1), are quite high in class by live weight pretty much as boar pigs. So, the total of 293 gilts had the following live weight class: elite $35.8 \%$, first class - $34.8 \%$, second class $-21.1 \%$ and only $8.1 \%$ were out of class.

Table 8. Evaluation of purebred gilts obtained from experimental boars by torso length.

\begin{tabular}{|c|c|c|c|c|c|}
\hline \multirow[t]{2}{*}{ Boars line } & \multirow{2}{*}{$\begin{array}{l}\text { The number } \\
\text { of grown } \\
\text { boar pigs up } \\
\text { to } 6 \text { months } \\
\text { of age, } \\
\text { heads }\end{array}$} & \multicolumn{4}{|c|}{ Gilts' class by torso length } \\
\hline & & elite & 1 & 2 & out of class \\
\hline Olymp V & 145 & 49 & 53 & 32 & 11 \\
\hline Topigs 1 & 148 & 47 & 56 & 31 & 14 \\
\hline $\begin{array}{l}\text { On average } \\
\text { by lines }\end{array}$ & 293 & 96 & 109 & 63 & 25 \\
\hline
\end{tabular}

The data given in Table 8 also confirm gilts' high class by torso length. Here, $32.7 \%$ of gilts corresponded to the elite class, $37.2 \%$ - first class, $21.5 \%$ - second class, and $8.5 \%$ were out of class. These studies show that the cultivation of large white breed herd replacements is carried out at a sufficient level on the collective farm. But taking into account the fact that the farm has planned to create a breeding and genetic center for pig breeding and large white breed intra-breed type creation, these indicators must be improved. It is necessary to achieve such results so that the number of large white breed boar pigs and gilts' replacements at 6 months of age and of elite class was at least $50 \%$ of all grown in the farm.

Analyzing the results of conducted studies, it should be noted that the large white breed boars are characterized by high sperm production indicators. However, when sows were inseminated with large white breed boars' sperm, it was found out that the sows' prolificacy was equal to 12.1 piglets. Study of offspring growth shows that the average daily animals increase amounted to $576 \mathrm{~g}$. The obtained indicators' values are insufficient. They need to be increased to the level envisaged by the project. According to the project up to 2025, it is necessary to create a herd of large white breed sows in the amount of at least 400 heads 
with the following characteristics: sows' prolificacy - 13.5 heads, seat mass at birth -17.5 $\mathrm{kg}$, at 30 days $-134.9 \mathrm{~kg}$. The resulting offspring should correspond to the following indicators: the age of reaching $100 \mathrm{~kg}$ live weight: boar pigs - 160 days, gilts - 165 days; average daily gains from birth: boar pigs $-625 \mathrm{~g}$, gilts $-610 \mathrm{~g}$; feed consumption per $1 \mathrm{~kg}$ of gain: boar pigs - $2.4 \mathrm{~kg}$, gilts $-2.4 \ldots 2.5 \mathrm{~kg}$; thickness of fat over thoracic vertebrae 6-7: boar pigs $-15.0 \mathrm{~mm}$, gilts $-18,0 \mathrm{~mm}$; muscle depth: boar pigs $-55.0 \mathrm{~mm}$, gilts $-54.0 \mathrm{~mm}$. All this is expected to be achieved because of subsequent targeted research work.

In the first quarter (January-March) of 2020, the project participants analyzed the general state of pig breeding in Belgorod region and in the APCO "Kolkhoz named after Gorin". Based on the obtained results, a database of primary accounting of pigs' breeding traits was formed. In addition, the genetic situation of the large white pigs' breed herd was evaluated in order to control and adjust the breeding process. Blood was taken from 180 sows in order to determine the breeding value of animals using BLUP procedure and genomic analysis. Taking into account the results of genomic analysis, artificial insemination of sows was carried out. To create a large white intra-breed type, 314 sows and 15 boars were selected. 54 sows were also selected to form the female line of a large white breed. First generation offspring has been obtained as of now. At the same time, the prolificacy aomunted to: intra-breed type - 13.8, female line - 14.9 heads (Table 9).

Table 9. Results of large white breed sows' farrowing.

\begin{tabular}{|c|c|c|c|c|c|c|}
\hline & \multirow{2}{*}{$\begin{array}{c}\text { Number of } \\
\text { Large white breed }\end{array}$} & \multicolumn{2}{|c|}{ Obtained piglets, heads } & \multicolumn{3}{|c|}{ Selected for growing, heads } \\
\cline { 3 - 7 } & $\begin{array}{c}\text { sows, } \\
\text { heads }\end{array}$ & Total & $\begin{array}{c}\text { For 1 } \\
\text { farrowing }\end{array}$ & Total & $\begin{array}{c}\text { Boar } \\
\text { pigs }\end{array}$ & Gilts \\
\hline Intra-breed type & 103 & 1419 & 13,8 & 294 & 27 & 267 \\
\hline Female line & 30 & 448 & 14,9 & 92 & 8 & 84 \\
\hline
\end{tabular}

According to the program, all obtained livestock is evaluated using immunogenotypic and DNA tests. A method of estimating the animals' breeding value on the basis of the BLUP-procedure is being introduced. Information databases on BLUP and FIAS programs have been created. By the end of this year it is planned to assess the reproductive, feeding and meat qualities of pigs of both generations, including the quality of meat of the first generation pigs. To solve the problems of increasing the indicators of hardly selectable traits - sows' prolificacy, the preservation and enhancement of piglets' viability — high genetic technologies for the purpose of obtaining animals with an altered genome is supposed to be used.

\section{Conclusions}

In 2020, a breeding program was launched to obtain the large white intra-breed type in Belgorod region. To date, the first generation of offspring has been obtained and work to grow it and assess the breeding qualities is underway. At the same time, both traditional breeding methods and modern approaches are used, allowing to speed up the selection process.

Until 2025, on the basis of introduction, development and practical use of high-tech breeding work methods, the creation program of large white pigs' intra-breed type in Belgorod region is intended to create a type of pigs capable of competing with the best foreign breeding achievements - not only in terms of productivity, especially obtaining up to four tons of pork in a live weight from one sow per year, but the most important thing is to give the heterosis effect when used in hybridization programs.

The implementation of such projects contributes to improving the competitiveness of agro-industrial complex's products of Russia and Belgorod region, as well as import 
substitution and provision of scientific, technical, technological, breeding and genetic independence of our country in the field of animal husbandry.

\section{References}

1. S.N. Alejnik, G.S. Pohodnya, A.N. Dobud'ko, OOO IPC «Politerra», 30 (2020)

2. A.M. Hohlov, G.S. Pohodnya, Agrarnaya nauka, 10, 13 (2006)

3. I.F. Gorlov, L.A. Breusova, Bulletin of the Russian Academy of agricultural Sciences, 1, 31 (2013)

4. N.I. Zhernakova, A.N. Dobud'ko, T.A. Malahova, Belgorodskij GAU, 27 (2016)

5. S.N. Alejnik, Dostizheniya nauki i tekhniki APK, 6, 26 (2008)

6. G.S. Pohodnya, Belgorodskaya GSKHA, 38 (2006)

7. Yu.P. Breslavec, Belgorodskij GAU, 37 (2015)

8. A.T. Mysik, G.S. Pohodnya, T.A. Malahova, et al. Zootekhniya, 3, 24 (2020)

9. G.I. Gorshkov, A.G. Narizhnyj, E.G. Fedorchuk, Zootekhniya, 5, 8 (2014)

10. L.N. Gamko, D.K. Ufimcev, Kormoproizvodstvo, 2, 45 (2011)

11. A.T. Mysik, N.N. Sorokina, N.B. Ordina, 12, 14 (2019)

12. J. Beck, PLOS ONE, 5, 10 (2018)

13. H. Hammami, B. Rekik, C. Bastin, J. Dairy Sci., 92, 4604 (2019)

14. J. Lewis, J. Abas, C.Dadousis, PLOS ONE, 6, 18 (2015)

15. E. Seroussi, Glick, A. Shirak, BMC Genomics, 11, 673 (2015)

16. J. Weller, M. Ron, Dairy Sci., 94, 1082 (2016)

17. M. Gautier, D. Laloë, K. Moazami-Goudarzi, PLOS ONE, 5, 13 (2016) 